\title{
How smoking became history: looking back to 2012
}

\author{
Richard A Daynard
}

Public Health Advocacy Institute, Northeastern University School of Law, Boston, Massachusetts, USA

\section{Correspondence to} Richard A Daynard, Public Health Advocacy Institute Northeastern University, Liability Project, Northeastern University School of Law, 400 Huntington Avenue, Boston, MA 02115, USA; r.daynard@neu.edu

Received 9 March 2011 Accepted 30 July 2011
Geneva, 21 March 2032: As we all know, the work of tobacco control today is focused on reducing the prevalence and harm from nonsmoked tobacco products, caring for ex-smokers with cigarette-caused diseases with long latencies and stamping out cigarette smuggling where it still arises. But many of our readers are old enough to have spent most of their tobacco control careers fighting cigarettes. They were facing over five million tobacco-related deaths in 2012, and the prospect of a billion such deaths this century, with cigarettes by far the main culprit. Many assumed that cigarettes would always be with us: indeed, the original Framework Convention on Tobacco Control focused on imposing warnings, prohibiting advertisements, raising taxes and protecting nonsmokers from 'secondhand smoke' (what people used to be exposed to in the presence of combusted tobacco products). Indeed, they pursued every promising idea short of getting rid of cigarettes and other burned tobacco products. That just seemed a bridge too far.

So what happened to make smoked tobacco products 'history' and thereby improve the health and life expectancy of millions of people around the world? The story will be familiar to most readers, but it is worth reviewing, especially for younger tobacco control workers who find it hard to believe that the sale of cigarettes was ever permitted.

The story begins with the fact that in the first dozen years of this century, the general public was ahead of the tobacco control 'mainstream' in realising that cigarettes had to go. Polls in the USA, ${ }^{1}$ Great Britain, ${ }^{2}$ New Zealand ${ }^{3}$ and elsewhere produced almost identical results: over $40 \%$ of the public thought cigarettes should be banned, almost as many as thought the contrary. Some polls, as in Mauritius, showed even stronger support, ${ }^{4}$ and strong majorities in the USA were in favour of getting rid of the addictive components in cigarettes. ${ }^{5}$ These polls preceded the rare calls by public figures, such as Ilkka Oksala, the Finnish State Secretary in the Health Ministry, ${ }^{6}{ }^{7}$ and David Kessler, the former US Food and Drug Administration (FDA) Commissioner, ${ }^{8}$ for such a ban: the people figured it out for themselves! After all, it simply never made sense that a product that is highly addictive, kills half its regular users and is freely 'chosen' only by children and teenagers, continued to be sold when it satisfied no preexisting human need and when less toxic alternatives existed for smokers who could not quit entirely. ${ }^{9}$

Even among those who believed it could be done, there was much discussion 20 years ago about how best to eliminate smoked tobacco products from the market. Some people suggested squeezing the supply by annually reducing a cap on the number of cigarettes that could be sold in a particular country. ${ }^{10}$ Others advocated picking a date to end sales of cigarettes and other smoking tobacco and sticking to it (backed up by other policies to ease the transition). ${ }^{11}$ Still others suggested picking an age cohort (say, anyone born after 1999) and making it illegal to sell cigarettes to them. ${ }^{12}$ And some said, 'just remove the nicotine from the cigarettes, and let the smokers finally make a genuinely free choice. ${ }^{7}$

Of course, designing viable and effective policies is a matter partly of logic but mostly of trial and error. The cap reduction proved too complex administratively. Bhutan banned the sale of tobacco products in 2004 - but almost no one noticed! ${ }^{13}$ New Zealand went for a ban in 2020, which went so smoothly that many countries followed suit with much shorter lead times. Those who had been worried that a country adopting a ban would need, like New Zealand, to have ocean on all sides were reassured when the smoking rate dropped below $10 \%$ even before the ban took effect: it turns out that so long as cessation assistance, including a variety of non-combusted nicotine delivery devices, is available, along with regular tax increases and a focused media campaign leading up to the ban, there is little residual demand for smuggled cigarettes.

Singapore went ahead with a ban on sales to anyone born in the 21st century. This was adopted in 2012 near the time the World Conference on Tobacco or Health was held there. There is obviously no peer pressure for young people to smoke, and the few remaining older smokers get the pity they deserve. A few other countries jumped on the 1999 cut-off date; later arrivals have used dates early in the first decade.

The US FDA, operating under explicit statutory authority to reduce but not eliminate nicotine in any tobacco product, decided in 2013 to reduce nicotine levels in smoked products to non-addictive levels. The tobacco industry tried arguing in court that the essence of a cigarette is its ability to induce and sustain nicotine addiction' but ran into trouble both with its earlier vehement denials of addictiveness as well as with the fact that the policy of suppressing other addictive drugs had been frequently affirmed and had withstood constitutional challenges. Once the tobacco and pharmaceutical industries turned their full attention to making non-smoked products for addicted smokers, the threat that the rule would be repealed receded. With the huge US market smokefree, many other countries simply adopted the FDA rule as their own. And the FDA is now completing the process of phasing out nicotine from the most toxic non-smoked products currently on the market. 


\section{What the paper adds}

Looking back 20 years from 2032, we find that many proposals for phasing out smoked tobacco products under discussion in 2012 were actually implemented, with the result that tobacco smoking was largely extinguished by 2032.

Like the eradication or amelioration of many common infectious diseases in the 20th century, the elimination of smoking seemed well-nigh impossible in prospect; in retrospect, it is the great public health achievement thus far of the 21st century.

Competing interests None.

Provenance and peer review Commissioned; externally peer reviewed.

\section{REFERENCES}

1. Zogby International. A Federal Ban On Cigarettes? Nationwide Survey Of 1,200 Registered Voters. Utica, New York: Zogby International for Drug Policy Alliance, 2006. http://www.drugpolicy.org/docUploads/DPAZogbyTobaccoPoll2006.pdf (accessed 26 Feb 2011).

2. Shahab L, West R. Public support in England for a total ban on the sale of tobacco products. Tob Control 2010;19:143-7.
3. Thomson G, Wilson N, Edwards R. Kiwi support for the end of tobacco sales: New Zealand governments lag behind public support for advanced tobacco control policies. N Z Med J 2010;123:106-11.

4. ITC Project. ITC Mauritius National Report. Results of the Wave 2 Survey. Ontario Canada: University of Waterloo; Pamplemousses, Mauritius: Mauritius Institute of Health (MIH), 2011. http://www.itcproject.org/documents/keyfindings/ itc20mauritius20reportprintdraftpdf.

5. Winikoff J, McMillen R, Abrams D, et al. National attitudes about FDA's potential regulatory actions in the family smoking prevention and tobacco control act of 2009 . In: Society for Research on Nicotine and Tobacco, 15th Annual Meeting 23-37. Baltimore, Maryland, USA, 2010. [Poster presentation P0S5-8]. http://www. socialclimate.org/pdf/PAS 2010 FDA.pdf (accessed 18 Aug 2011).

6. BBC News. Finland Aims To Stub Out Smoking Habit, 2010. http://news.bbc.co.uk/ 2/hi/8459947.stm (accessed 26 Feb 2011).

7. Ministry of Social Affairs and Health. The Aim Of The Tobacco Act Is To Put An End To Smoking In Finland [Finnish Government Media Release]. Helsinki: Ministry of Social Affairs and Health. http://www.ensp.org/node/233.

8. Layton L. Fda Should Use Its Power To Lower Nicotine In Cigarettes, Former Chief Says. Washington Post, 2010. http://www.washingtonpost.com/wp-dyn/content/ article/2010/06/16/AR2010061605340.html (accessed 26 Feb 2011).

9. Daynard R. Doing the unthinkable (and saving millions of lives). Tob Control 2009;18:2-3.

10. Thomson G, Wilson N, Blakely T, et al. Ending appreciable tobacco use in a nation: using a sinking lid on supply. Tob Control 2010;19:431-5.

11. Laugesen M, Glover M, Fraser $\mathrm{T}$, et al. Four policies to end the sale of cigarettes and smoking tobacco in New Zealand by 2020. N Z Med J 2010;123:55-67.

12. Khoo D, Chiam $\mathrm{Y}, \mathrm{Ng} \mathrm{P}$, et al. Phasing-out tobacco: proposal to deny access to tobacco for those born from 2000. Tob Control 2010;19:355-60.

13. BBC News. Bhutan Forbids All Tobacco Sales, 2004. http://news.bbc.co.uk/2/hi/ south asia/4012639.stm (accessed 25 Jul 2011). 